\title{
Pendampingan Agribisnis Anggrek Hibrida di Kecamatan Matesih Kabupaten Karanganyar
}

\author{
Sri Hartati ${ }^{1,2^{*}}$ dan Ongko Cahyono ${ }^{3}$ \\ ${ }^{1}$ Pusat Penelitian dan Pengembangan Bioteknologi dan Biodiversitas LPPM UNS \\ ${ }^{2}$ Program Studi Agroteknologi Fakultas Pertanian UNS \\ ${ }^{3}$ Program Studi Ilmu Tanah Fakultas Pertanian UNS \\ *Correspoding Author : tatik_oc@yahoo.com \\ Dikirim: 28-10-2020; Diterima: 02-07-2021
}

\begin{abstract}
ABSTRAK
Kecamatan Matesih Karanganyar dikenal sebagai pusat tanaman hias termasuk tanaman anggrek. Umumnya, petani hanya membesarkan anggrek remaja menjadi anggrek dewasa yang kemudian dijual. Petani belum bisa melakukan pemindahan benih dari botol kultur jaringan ke media dalam pot. Kegiatan pengabdian kepada masyarakat bertujuan untuk memberikan pengetahuan dan menambah keterampilan petani mitra dalam melakukan aklimatisasi pada anggrek hibrida. Diharapkan petani dapat melakukan pemindahan benih anggrek dengan tingkat keberhasilan tinggi sehingga keuntungan dari agribisnis anggrek meningkat. Pendampingan telah dilakukan di Desa Plosorejo, Kecamatan Matesih, Kabupaten Karanganyar pada bulan April sampai Oktober 2020. Petani mitra terdiri dari dua kelompok tani yakni Kelompok Tani RT 002 RW XIII dan Kelompok Tani Rejo IX. Program kemitraan masyarakat ini berhasil meningkatkan pengetahuan dan keterampilan petani mitra dalam melakukan aklimatisasi anggrek hibrida. Kegiatan ini secara bisnis menguntungkan karena hasil perhitungan usaha tani dengan modal sebesar Rp. 869.000,00 menghasilkan keuntungan sebesar Rp. 1.311.000,00 per empat bulan dengan BC ratio sebesar 1,5.
\end{abstract}

Kata kunci: aklimatisasi, hibrida, invitro, kultur jaringan, planlet

\section{The Assistance of Hybrid Orchid Agribusiness in Matesih District Karanganyar Regency}

\begin{abstract}
Matesih District of Karanganyar Regency is known as the center of ornamental plants including orchids. However, most of the farmers grow orchids by raise the juvenile orchids into adult orchids which are then sold. Farmers have not been able to produce seedlings as well as to transfer plantlets from tissue culture bottles to media in pots. These community service programs aim to provide knowledge and increase the skills of partner farmers in acclimatizing hybrid orchids. Therefore they can transfer orchid seeds with a high success rate and earn higher profits from their orchid agribusiness. The program was carried out in Plosorejo Village, Matesih District, Karanganyar Regency from April to October 2020. Partner farmers consist of two farmer groups, namely the farmer group of RT 002 RW XIII and Tani Rejo IX. This program has succeeded in increasing the knowledge and skills of partner farmers in acclimatizing hybrid orchids. In terms of business, this program is profitable because based on the calculation with a capital of Rp869.000, 00 generates a profit of Rp1.311.000,00 per four months with a BC ratio of 1.5.
\end{abstract}

Keywords: acclimatizing, hybrids, in vitro, tissue culture

\section{PENDAHULUAN}

Indonesia memiliki letak geografis yang tropis dengan curah hujan yang tinggi. Hal berada di daerah tropika basah, yaitu daerah tersebut menyebabkan Indonesia menjadi negara 
dengan biodiversitas yang tinggi bagi flora maupun fauna, termasuk tanaman anggrek. Indonesia memiliki jenis anggrek lebih dari 25.000 spesies yang banyak digunakan sebagai industri atau anggrek potong (Chase, 2005; Hartati et al., 2017; Kuehnle, 2007). Salah satu wilayah di Indonesia yang menjadi sentra produksi anggrek yaitu Kabupaten Karanganyar yakni suatu Kabupaten di Provinsi Jawa Tengah yang terletak di bagian barat utara kaki Gunung Lawu. Karanganyar memiliki wilayah yang subur dan agroklimat yang mendukung untuk pertumbuhan berbagai tanaman termasuk tanaman hias. Bahkan Karanganyar pernah mendapat sebutan Kabupaten Anthurium pada tahun 2007 karena kejayaan tanaman Anthurium pada saat itu. Seiring dengan berjalannya waktu meskipun Anthurium tidak lagi berjaya, Karanganyar masih menjadi daerah sentra produksi tanaman hias, terutama tanaman anggrek.

Anggrek termasuk famili Orchidaceae yang tergolong tanaman berbunga dengan banyak spesies dan keragaman karakter dengan berbagai pola diferensiasi genetik antar populasi (Niknejad et al., 2009). Keragaman tanaman anggrek banyak diteliti oleh para ahli anggrek. (Hartati \& Darsana, 2015) melaporkan bahwa keragaman anggrek beberapa genus mencapai 50-100\%. Selanjutnya (Hartati et al., 2014) melaporkan bahwa keragaman genetik pada anggrek Coelogyne spp. berkisar 0,23-0,54. Keragaman genetik anggrek dapat ditingkatkan melalui persilangan. Cara tersebut banyak dilakukan para pemulia.

Tanaman anggrek dapat dikategorikan menjadi anggrek alam dan anggrek hibrida. Anggrek alam (anggrek spesies) adalah anggrek yang hidup di habitat asalnya dan belum mengalami persilangan. Habitat asli anggrek ini umumnya berupa hutan dengan kondisi lingkungan yang sesuai dengan syarat tumbuh anggrek tersebut. Anggrek alam dapat dijadikan sebagai tanaman induk dalam persilangan untuk mendapatkan jenis anggrek baru (Agustin \& Widowati, 2015).

Anggrek hibrida adalah anggrek yang diperoleh dari proses persilangan. Proses penyilangan ini akan menghasilkan hibrida interspesifik, hibrida intraspesifik, hibrida intergenik/multigenik. Hasil dari persilangan anggrek ini akan menghasilkan keanekaragaman sifat yang besar yang kemudian dapat diperbanyak secara massal menggunakan teknik kultur jaringan (Purba \& Saptadi, 2019).
Teknologi budidaya anggrek terus mengalami perkembangan, diantaranya perbanyakan tanaman melalui teknik kultur jaringan, atau yang disebut dengan teknik in vitro. Hasil tanaman kultur jaringan tidak bisa langsung ditanam di lapangan, melainkan harus dilakukan penyesuaian atau adaptasi dari benih yang semula tumbuh dalam media kultur ke media tumbuh alaminya misalnya arang dan spagnum. Tahapan ini disebut dengan aklimatisasi yang merupakan tahap akhir dari teknik kultur jaringan dimana setelah itu tanaman akan ditumbuhkan dalam lingkungan alamiahnya.

Aklimatisasi merupakan fase kritis dari tahapan teknik kultur jaringan karena merupakan fase yang seringkali menentukan hidup matinya tanaman. Aklimatisasi merupakan tahapan yang sulit dilakukan dan perlu ketelitian dan pengalaman agar tanaman berhasil hidup. Pemilihan media untuk anggrek tidak hanya sebagai penyedia unsur hara, namun juga perlu memperhatikan fungsi lainnya seperti menjadi tempat melekat akar, mampu menjaga kelembapan, serta daya simpan air tinggi (Herliana et al., 2018). Media tumbuh untuk anggrek yang baik mempunyai rongga untuk pasokan udara, mudah ditembus akar, dan juga harus mempunyai kemampuan menyimpan air (Herliana et al., 2018; Suradinata et al., 2012).

Disamping pemilihan media, faktor lain yang menentukan keberhasilan aklimatisasi adalah pengaturan cahaya matahari yang masuk dan tindakan perawatan seperti pemberian air, pemupukan, dan perlindungan tanaman dari hama dan penyakit. Apabila faktor-faktor di atas dapat dilakukan dengan tepat, maka benih anggrek dapat tumbuh dengan baik. Namun sebaliknya, jika penanganannya tidak tepat, misalnya media tidak sesuai, maka besar kemungkinannya benih tidak berhasil hidup.

Pertumbuhan benih anggrek memerlukan ketersediaan nutrien baik unsur hara makro maupun mikro. Unsur-unsur ini biasanya tidak tersedia dengan cukup dalam media tumbuhnya, sehingga harus disediakan melalui pupuk (Suradinata et al., 2012). Penyediaan unsur hara pada tanaman anggrek pada tahap aklimatisasi bisa diberikan lewat akar yakni dengan menyiramkan ke media dan juga bisa lewat daun yakni dengan menyemprotkan pupuk cair ke daun.

Aplikasi pupuk daun pada tanaman anggrek mempunyai kelebihan dibandingkan pemupukan lewat akar, yakni unsur hara makro 
dan mikro dari pupuk akan lebih cepat tersedia dan akan lebih mudah masuk ke dalam sel tanaman melalui stomata. Oleh karena itu, penyediaan nutrien untuk tanaman anggrek pada tahap aklimatisasi yang dianjurkan adalah aplikasi pupuk cair lewat daun.

Dalam aplikasi pupuk daun, harus diperhatikan dua hal penting yakni frekuensi dan konsentrasi pemberian. Frekuensi pemberian yang tidak tepat akan menghasilkan pertumbuhan yang kurang ideal. Jika frekuensinya kurang akan menyebabkan tanaman kekurangan unsur hara sehingga pertumbuhannya lambat dan kerdil. Sebaliknya jika pemberiannya terlalu sering maka di samping akan menyebabkan pemborosan juga bisa mengakibatkan kematian tanaman akibat keracunan.

Pemberian pupuk yang tepat akan berpengaruh nyata terhadap pertumbuhan tanaman (Dwiyani, 2012). Hasil penelitian menunjukkan bahwa penyemprotan 3 hari sekali memiliki tinggi tanaman lebih baik, yakni 5,25 $\mathrm{cm}$, daripada penyemprotan 10 hari sekali, yakni hanya $2,5 \mathrm{~cm}$. Pupuk daun diaplikasikan pada tanaman saat pagi hari yang mana stomata membuka lebih lebar jika dibandingkan pada saat siang hari dikarenakan saat siang hari stomata menutup untuk mengurangi kehilangan air (Andalasari et al., 2017).

Waktu aplikasi pupuk juga menjadi perhatian penting, karena akan mempengaruhi efektifitas penyerapan oleh tanaman sehingga menentukan baik buruknya proses pertumbuhan dan perkembangan benih (Surtinah \& Mutryarny, 2013). Sukma and Setiawati (2010) melaporkan bahwa pupuk daun untuk anggrek Dendrobium dapat diaplikasikan pada pagi, siang, atau sore hari. Pemupukan pada sore hari dapat meningkatkan panjang daun pertama teratas dan kandungan $\mathrm{N}$ total pada daun. Aplikasi pupuk daun setiap tiga hari sekali dapat mempercepat pertumbuhan daun pertama teratas/daun muda. Frekuensi pemupukan tiga hari sekali menghasilkan jumlah kuntum bunga per tangkai yang lebih banyak.

Teknologi budidaya banyak menghasilkan anggrek tipe baru. Jenis-jenis anggrek hibrida berpotensi untuk dikembangkan di Plosorejo Kecamatan Matesih yang mempunyai iklim yang cocok untuk tanaman anggrek. Adapun permasalahan yang dialami oleh desa mitra yaitu petani pembudidaya anggrek di desa sasaran belum memiliki kemampuan sebagai petani penangkar dengan teknologi kultur jaringan.
Hampir semua petani anggrek di desa ini adalah petani yang hanya membesarkan anggrek dari benih menjadi anggrek dewasa (berbunga), petani anggrek di desa sasaran belum memiliki pengetahuan dan keterampilan tentang aklimatisasi benih anggrek hibrida. Di samping itu, petani anggrek di desa sasaran belum memiliki pengetahuan dan keterampilan dalam melakukan teknik perawatan benih anggrek hasil kultur jaringan pada tahap aklimatisasi. Pengembangan teknik budidaya pada agribisnis dilakukan untuk meningkatkan pendapatan petani anggrek (Andri \& Tumbuan, 2015).

Berdasarkan permasalahan di atas, dalam kegiatan ini petani mitra diberikan pelatihan secara teoritis dan praktik bagaimana melakukan aklimatisasi benih anggrek mulai dari teknik mengeluarkan benih dari dalam botol, menanam benih dalam media spaghnum, memindahkan benih ke dalam pot individu dan merawat benih sampai menjadi tanaman anggrek remaja yang siap berbunga. Tujuan dari kegiatan pendampingan ini adalah untuk memperkenalkan produk benih anggrek kultur jaringan dan teknik aklimatisasi benih kultur jaringan tersebut agar keterampilan dan pengetahuan petani mitra meningkat, sehingga diharapkan melalui kegiatan pendampingan ini dapat meningkatkan pendapatan masyarakat Plosorejo melalui usaha agribisnis anggrek.

\section{METODE}

Program Kemitraan Masyarakat (PKM) telah dilaksanakan di Desa Plosorejo, Matesih Karanganyar pada bulan Mei sampai Agustus 2020. Lokasi berada pada ketinggian 660 meter di atas permukaan laut. Pelaksanaan kegiatan PKM ini melibatkan 2 mitra, yaitu Kelompok Tani RT 002 RW XIII dan Kelompok Tani Rejo IX yang masing-masing beranggotakan 12 orang. Alat dan bahan yang diperlukan antara lain: benih anggrek hibrida Phalaenopsis dalam botol, sebanyak 10 botol, pot besar sebanyak 10 buah, pot kecil sebanyak 80 buah, media tanam sphagnum, arang, fungisida Dithane, sprayer punggung, dan hand sprayer.

Kegiatan pengabdian masyarakat ini dilaksanakan dengan metode demplot (demonstrasi plot) dengan memberikan pelatihan secara teori dan praktik. Pelaksanaan kegiatan dilaksanakan melalui tahapan-tahapan sosialisasi program kemitraan masyarakat, penyuluhan, praktik, dan monitoring-evaluasi. Pada tahap sosialisasi program, tim PKM 
mengadakan pertemuan dengan perwakilan petani anggrek yang merupakan anggota kelompok tani sasaran untuk menyampaikan maksud dan tujuan program kemitraan masyarakat, tatacara pelaksanaan, pendataan anggota kelompok yang akan ikut dalam program ini serta hak dan kewajiban peserta. Tahap berikutnya adalah penyuluhan, yakni Tim PKM UNS memberikan penyuluhan dan pelatihan secara teoritis tentang keunggulan teknologi budidaya anggrek secara kultur jaringan, teknik pemindahan benih dari media kultur ke media arang sphagnum, serta teknik aklimatisasi benih anggrek hasil kultur jaringan.

Setelah mendapat pelatihan secara teori, petani mitra mendapat kesempatan untuk melakukan praktik pemindahan benih dari dalam botol, penanaman benih ke media arang sphagnum, melakukan pemindahan benih dalam pot individu sekaligus perawatannya. Dalam kesempatan ini petani juga dilibatkan untuk mengamati pertumbuhan benih anggrek antara lain jumlah benih yang hidup, pertambahan tinggi benih, jumlah daun, dan lebar daun. Petani juga dilibatkan dalam membuat analisis perhitungan bisnis secara sederhana.

Tahap berikutnya adalah monitoring dan evaluasi. Tujuan kegiatan pada tahap ini adalah untuk mengevaluasi kegiatan yang sudah diberikan baik dari segi manfaat maupun hambatan setelah diberikan kegiatan PKM. Kegiatan monitoring meliputi pengamatan terhadap pertumbuhan benih anggrek setiap seminggu sekali sampai waktu 3 bulan setelah tanam, meliputi: tingkat keberhasilan hidup benih, pertambahan tinggi benih, jumlah daun, lebar daun, dan panjang daun. Kegiatan evaluasi dilakukan untuk mengetahui tingkat keberhasilan program, yakni meliputi: keseriusan peserta dalam mengikuti program yang dinilai dari tingkat kehadiran dan bertambahnya pengetahuan dan keterampilan peserta dengan cara wawancara. Kegiatan evaluasi juga dilakukan dengan melakukan uji analisis usaha tani untuk mengetahui kelayakan usaha yang dilakukan.

\section{HASIL DAN PEMBAHASAN}

\section{Sosialisasi Program Kemitraan Masyarakat Pelaksanaan sosialisasi dengan} perwakilan kelompok tani mitra dilaksanakan pada tanggal 13 Juni 2020 bertempat di rumah ketua RW XIII. Pada tahap ini disepakati bahwa kegiatan PKM melibatkan 2 mitra, yaitu Kelompok Tani RT 002 RW XIII dan Kelompok Tani Rejo IX, masing-masing beranggotakan 12 orang. Dalam hasil pertemuan juga disepakati bahwa mengingat kondisi pandemi, pelaksanaan program kegiatan akan dilaksanakan pada bulan Juli atau Agustus 2020.

\section{Penyuluhan dan Pelatihan}

Penyuluhan dilaksanakan pada tanggal 4 Juli 2020 pukul 20.00-22.00 WIB bertempat di rumah Bapak Suyatno, salah satu anggota kelompok mitra. Tim PKM UNS memberikan penyuluhan tentang teknik aklimatisasi benih anggrek hibrida meliputi: tindakan pengeluaran benih dari botol, teknik penyiapan media spagnum dalam pot, penanaman benih dalam pot, pencahayaan pada benih, dan teknik pemupukan. Penyuluhan dilakukan dengan ceramah menggunakan media LCD dan video. Dalam pelaksanaan penyuluhan ini, peserta yang mengikuti kegiatan PKM terlihat sangat antusias (Gambar 1 dan Gambar 2). Hal ini bisa dilihat dari tingkat kehadiran peserta pada saat pelaksanaan penyuluhan. Hal ini tidak mengherankan karena petani mitra yang mengikuti program ini adalah kelompok tani pengembang tanaman anggrek di Desa Plosorejo, Kecamatan Matesih, Kabupaten Karanganyar yang sudah memiliki ketertarikan terhadap tanaman anggrek.

\section{Praktik}

Pelaksanaan praktik dimulai pada tanggal 6 Juli bertempat di rumah salah satu anggota kelompok mitra, Bapak Suyatno di Desa Plosorejo Rt. 04 Rw. XIII, Kecamatan Matesih, Kabupaten Karanganyar (Gambar 3). Kegiatan ini bertujuan untuk memberikan kesempatan pada peserta untuk melakukan secara mandiri teknik aklimatisasi, sehingga pengetahuan dan keterampilan para peserta dalam teknik budidaya anggrek hibrida bertambah. Pada kegiatan ini, peserta melakukan praktik pemindahan planlet anggrek hibrida Phalaenopsis ke dalam pot besar. Tiap kelompok melakukan praktik yakni melakukan pemindahan 5 (lima) botol yang tiap botol berisi 8 planlet anggrek.

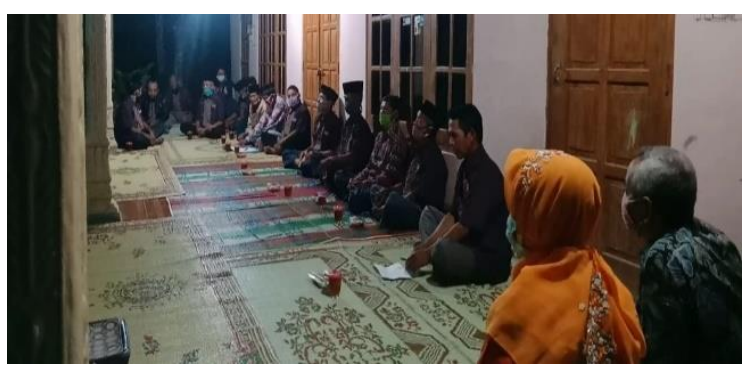

Gambar 1. Peserta dari bapak-bapak yang hadir pada kegiatan penyuluhan 


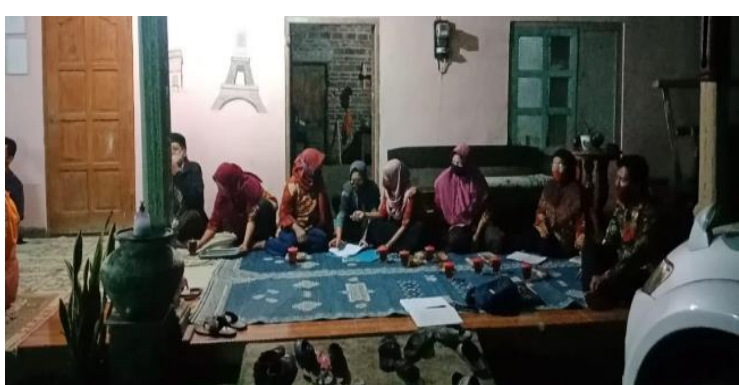

Gambar 2. Peserta dari Ibu-Ibu yang hadir pada

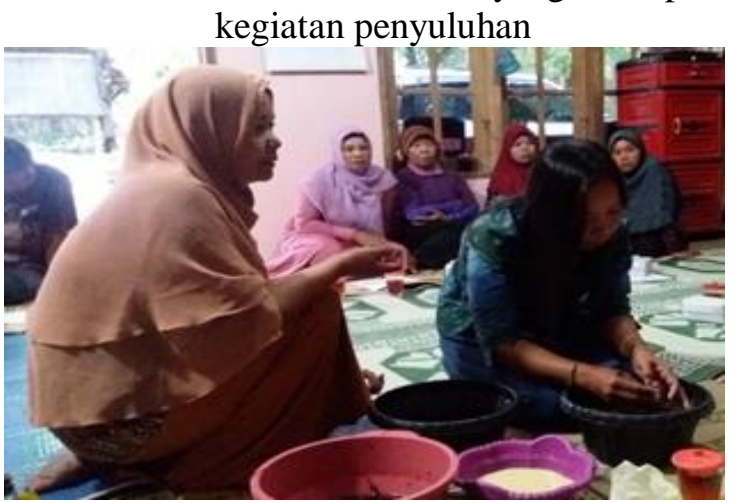

Gambar 3. Peserta melakukan praktik menanam planlet dalam pot

Berikut tahapan aklimatisasi benih anggrek yang dilakukan oleh peserta:

\begin{tabular}{|c|}
\hline $\begin{array}{c}\text { Planlet anggrek dikeluarkan dari botol } \\
\text { kultur (Gambar 4) }\end{array}$ \\
\hline $\begin{array}{c}\text { Planlet ditanam ke pot yang berisi media } \\
\text { arang sphagnum (Gambar 5) }\end{array}$ \\
\hline $\begin{array}{c}\text { 4 minggu kemudian benih dipindah ke pot } \\
\text { individu yang berisi media arang sphagnum } \\
\text { (Gambar 6) }\end{array}$ \\
\hline
\end{tabular}

Benih tersebut kemudian dipelihara dengan menjaga kelembapan media, penambahan pupuk setiap 10 hari sekali, serta penyemprotan fungisida untuk melindungi tanaman dari serangan fungi. Pada tahapan ini para peserta juga melakukan pencatatan terhadap kemajuan pertumbuhan benih, yang terdiri atas jumlah benih yang hidup, tinggi tanaman, penambahan panjang daun, lebar daun, dan jumlah daun. Benih anggrek yang sudah dipindah pada pot dapat dilihat pada Gambar 5 dan Gambar 6.

\section{Monitoring dan Evaluasi}

Hasil pengamatan terhadap tingkat keberhasilan dan pertumbuhan benih anggrek disajikan pada Gambar 7. Hasil kegiatan ini menunjukkan bahwa dari total jumlah benih yang ditanam, lebih dari $90 \%$ benih berhasil hidup. Tingkat keberhasilan hidup dari benih anggrek yang dicapai oleh Kelompok I sejumlah 39 benih dari 40 benih anggrek yang dipindah atau sebesar $98 \%$, sedangkan keberhasilan hidup benih anggrek pada Kelompok II mencapai 95\%, dari 40 benih aklimatisasi terdapat 38 benih berhasil hidup.

Tingkat keberhasilan hidup yang tinggi dari benih anggrek menunjukkan bahwa peserta mampu menyerap ilmu pengetahuan yang diberikan tim PKM UNS dalam penyuluhan. Lebih lanjut keberhasilan pertumbuhan tanaman anggrek juga didukung oleh teknik perawatan yang memadahi, terutama dalam pemupukan dan pencegahan serangan penyakit yang disebabkan oleh jamur.
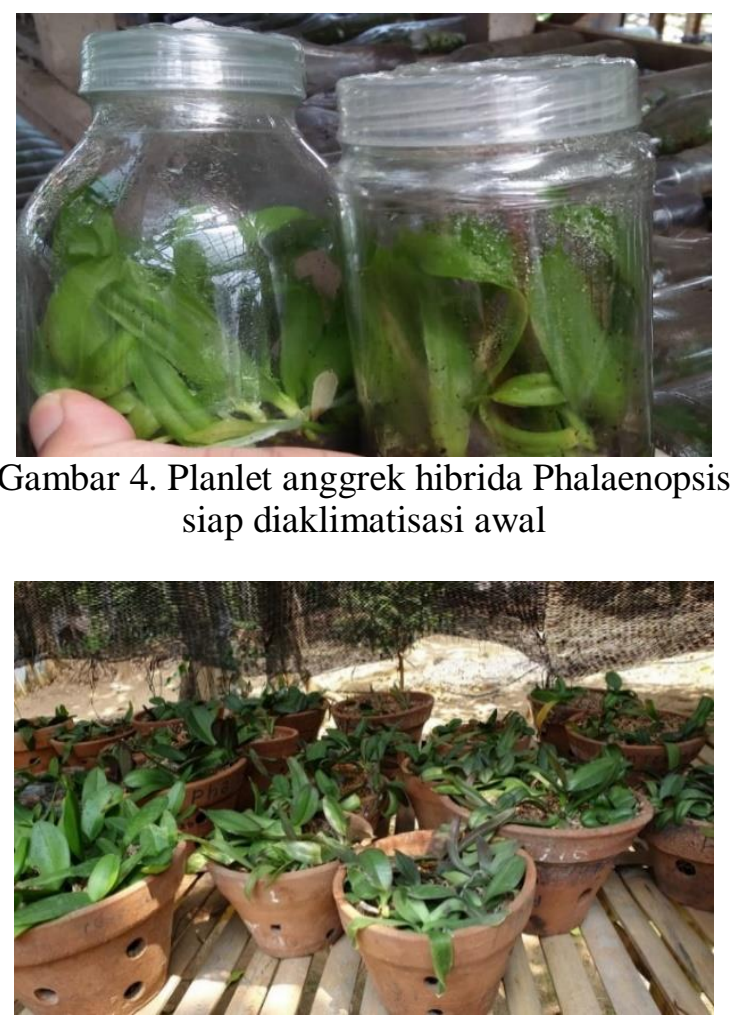

Gambar 5. Planlet anggrek yang sudah ditanam dalam pot sphagnum ditempatkan pada rak-rak dalam screen house

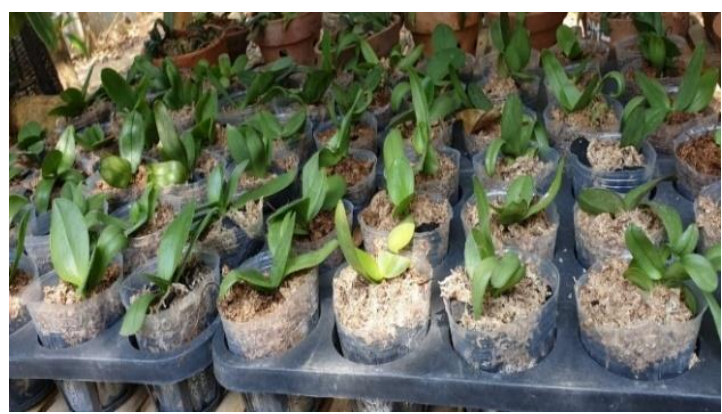

Gambar 6. Planlet anggrek yang sudah dipindah dalam pot individu 


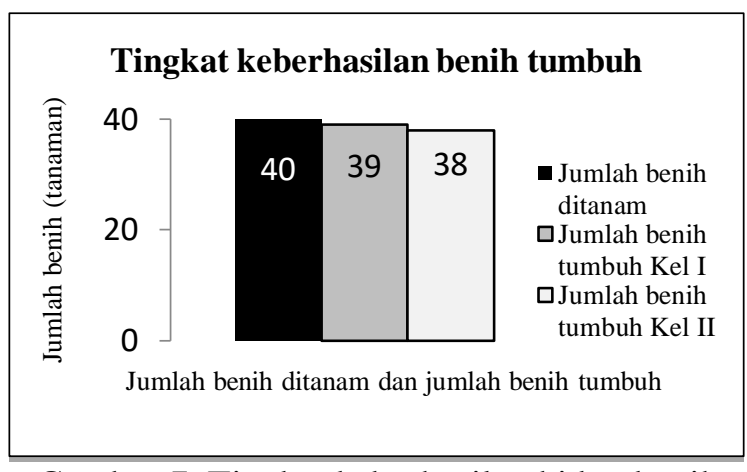

Gambar 7. Tingkat keberhasilan hidup benih anggrek

Jenis pupuk, konsentrasi, dan frekuensi aplikasi merupakan faktor yang mempengaruhi pertumbuhan benih anggrek. Pupuk yang digunakan dalam kegiatan ini adalah pupuk daun Growmore yang diberikan dengan konsentrasi 2 $\mathrm{ml}$ per liter air dengan frekuensi aplikasi 1 hari sekali sebanyak $10 \mathrm{ml}$ per tanaman. Pemupukan menentukan pertumbuhan benih karena tindakan ini dapat menyediakan unsur hara bagi tanaman anggrek yang tidak mampu mengambil unsur hara sendiri dari media yang ada.

Berdasarkan fase pertumbuhannya, jenis pupuk untuk tanaman anggrek dibedakan ke dalam dua jenis pupuk, yakni pupuk untuk memacu pertumbuhan dan pupuk untuk memacu pembungaan. Yang menjadi pembeda dari kedua pupuk ini adalah komposisi dari unsur hara yang dikandungnya. Pupuk untuk pertumbuhan tanaman biasanya mengandung unsur nitrogen yang lebih banyak dan diaplikasikan pada fase vegetatif. Sedangkan jenis pupuk yang kedua yakni pupuk untuk memacu pembungaan yang memiliki proporsi unsur fosfor lebih tinggi. Pupuk ini diaplikasikan menjelang fase pembungaan. (Widiastoety, 2008) membandingkan jenis pupuk nitrogen, Kalium Nitrat $\left(\mathrm{KNO}_{3}\right)$ dan Amonium Sulfat $\left(\mathrm{NH}_{4}\right)_{2} \mathrm{SO}_{4}$, yang diaplikasikan pada tanaman anggrek
Vanda. Hasil penelitian menunjukkan bahwa pemberian pupuk $\mathrm{KNO}_{3} 0,5 \%$ memperlihatkan pertumbuhan benih anggrek Vanda yang lebih baik, yakni benih lebih tinggi, daun benih lebih panjang, lebih lebar, lebih luas, jumlah daun lebih banyak, dan jumlah akar lebih banyak. Pupuk daun siap pakai yang ada di pasar misalnya Gandasil D memiliki kandungan nitrogen $(\mathrm{N})$ yang dominan. Kandungan nitrogen yang tinggi pada tanaman anggrek muda dapat memberikan hasil pertumbuhan yang lebih baik (Andalasari et al., 2017). Ketersediaan unsur nitrogen dalam pupuk penting untuk pembentukan klorofil sehingga kegiatan fotosintesis berjalan optimal (Surtinah \& Mutryarny, 2013).

Dalam kegiatan pelatihan ini petani mitra juga melakukan pengamatan terhadap komponen pertumbuhan tanaman anggrek, meliputi pengukuran tinggi tanaman, panjang daun, lebar daun, dan jumlah daun (Gambar 8). Hasil pengamatan pertumbuhan benih anggrek menunjukkan bahwa keterampilan peserta mitra baik kelompok I maupun kelompok II berimbang. Hal ini bisa dilihat dari pertumbuhan benih yang hampir sama baik tinggi tanaman, jumlah daun, panjang daun, maupun lebar daun.

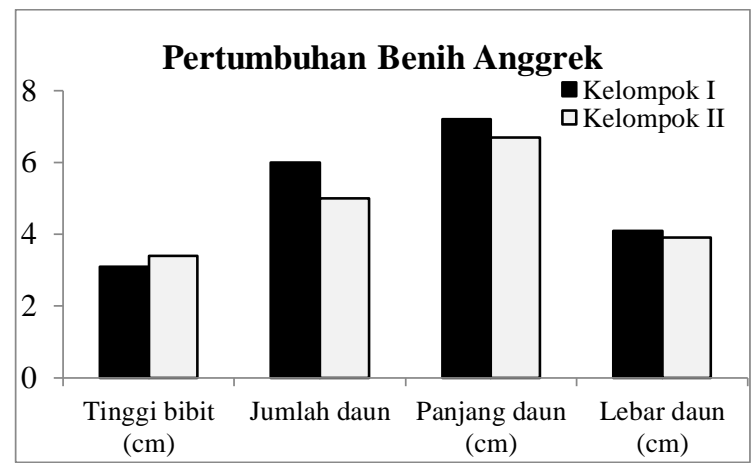

Gambar 8. Perbandingan komponen pertumbuhan benih anggrek pada Kelompok I dan Kelompok II

A. Pengeluaran (untuk 5 botol benih)

Tabel 1. Analisis bisnis anggrek

\begin{tabular}{|c|c|c|c|c|c|}
\hline \multirow[t]{8}{*}{ I } & Bahan & Kuantitas & Satuan & Harga satuan (Rp.) & Total (Rp.) \\
\hline & Benih anggrek & 5 & Botol & 75.000 & 375.000 \\
\hline & Pupuk Growmore hijau & 1 & Botol & 40.000 & 40.000 \\
\hline & Fungisida Dithane M-45 & 1 & Bungkus & 30.000 & 30.000 \\
\hline & Decis $2,5 \mathrm{EC}$ & 1 & Botol & 25.000 & 25.000 \\
\hline & Bactocyn & 1 & Botol & 40.000 & 40.000 \\
\hline & Sphagnum moss & 5 & Pak & 50.000 & 250.000 \\
\hline & Arang & 5 & Plastik & 10.000 & 50.000 \\
\hline \multirow[t]{3}{*}{ II } & Alat & & & & \\
\hline & Pot plastik besar & 5 & Buah & 4.000 & 20.000 \\
\hline & Pot plastik kecil & 40 & Buah & 1.000 & 40.000 \\
\hline \multicolumn{2}{|c|}{ Total Pengeluaran } & & & & 869.000 \\
\hline
\end{tabular}




\section{B. Pemasukan}

38 benih (yang tumbuh) $\times$ Rp60.000,00 = Rp2.280.000,00

C. Pendapatan (lama pemeliharaan 4 bulan) $\mathrm{B}-\mathrm{C}=\mathrm{Rp} 2.280 .000,00-\mathrm{Rp} 869.000,00=$ Rp1.311.000,00

D. Perhitungan $\mathrm{BC}$ ratio

$\mathrm{BC}$ ratio $=\mathrm{Rp} 1.311 .000,00 / \mathrm{Rp} 869.000,00$ $=1,5$

Pada kegiatan ini juga dilakukan analisis bisnis sederhana oleh mitra. Hasil perhitungan bisnis sederhana disajikan pada Tabel 1 .

Hasil perhitungan sederhana pada bisnis anggrek hibrida per 5 botol benih dengan 8 benih per botol jika dipelihara selama empat bulan memerlukan modal sebesar Rp. 869.000,00 di luar tenaga kerja. Pada analisis tersebut akan diperoleh pemasukan sebesar Rp. 2.280.000,00 dengan asumsi tingkat keberhasilan benih tumbuh sebesar $95 \%$ dan harga benih remaja yang dihasilkan memiliki harga Rp. 60.000,00 per tanaman. Pada perhitungan ini diperoleh BC ratio sebesar 1,5 yang berarti bisnis ini layak dijalankan.

\section{KESIMPULAN}

Teknologi budidaya anggrek berkembang pesat, sementara pengetahuan petani di daerah sasaran masih tradisional. Petani pembudidaya anggrek di desa sasaran belum memiliki kemampuan sebagai petani penangkar dengan teknologi kultur jaringan dan belum mempunyai keterampilan tentang aklimatisasi benih anggrek. Program kemitraan masyarakat ini berhasil menambah wawasan pengetahuan dan menambah keterampilan petani mitra dalam melakukan pemeliharaan benih anggrek hibrida hasil kultur jaringan. Kegiatan ini secara bisnis menguntungkan karena hasil perhitungan usaha tani dengan modal sebesar Rp. 869.000,00 menghasilkan keuntungan sebesar Rp. 1.311.000,00 per empat bulan dengan $\mathrm{BC}$ ratio sebesar 1,5. Perlu dilakukan tindak lanjut kegiatan pendampingan pemasaran anggrek secara online.

\section{UCAPAN TERIMA KASIH}

Penulis menyampaikan terima kasih kepada UNS melalui Program Kemitraan Masyarakat, dengan dana PNBP tahun Anggaran 2020 dengan surat perjanjian Nomor: 453/UN27.21/PN/2020.

\section{DAFTAR PUSTAKA}

Agustin, D., \& Widowati, H. (2015). Inventarisasi keanekaragaman anggrek (Orchidaceae) di hutan resort way kanan balai aman nasional way kambas sebagai sumber informasi dalam melestarikan plasma nutfah. Bioedukasi (Jurnal Pendidikan Biologi), 6(1), 38-46. https://doi.org/10.24127/bioedukasi.v6i1.1 56

Andalasari, T. D., Yafisham, Y., \& Nuraini, N. (2017). Respon pertumbuhan anggrek dendrobium terhadap jenis media tanam dan pupuk daun. Jurnal Penelitian Pertanian Terapan, 14(3), 167-173. https://doi.org/10.25181/jppt.v14i3.156

Andri, K. B., \& Tumbuan, W. J. A. (2015). Potensi pengembangan agribisnis bunga anggrek di Kota Batu Jawa Timur. Jurnal LPPM Bidang EkoSosBudKum, 2(1), 1930.

https://ejournal.unsrat.ac.id/index.php/lpp mekososbudkum/article/view/9297

Chase, M. W. (2005). Classification of orchidaceae in the Age of DNA data. Curtis's Botanical Magazine, 22(1), 2-7. https://doi.org/10.1111/j.13554905.2005.00466.x

Dwiyani, R. (2012). Respon pertumbuhan bibit anggrek Dendrobium sp. pada saat aklimatisasi terhadap beragam frekuensi pemberian pupuk daun. Agrotrop: Journal on Agriculture Science, 2(2), 171-175. https://ojs.unud.ac.id/index.php/agrotrop/ar ticle/view/7830

Hartati, S., \& Darsana, L. (2015). Karakterisasi anggrek alam secara morfologi dalam rangka pelestarian plasma nutfah. Jurnal Agronomi Indonesia, 43(2), 133-139. https://journal.ipb.ac.id/index.php/jurnalag ronomi/article/view/10419

Hartati, S., Nandariyah, N., Yunus, A., \& Djoar, D. W. (2017). Short Communication: Cytological studies on black orchid hybrid (Coelogyne pandurata Lindley). Biodiversitas: Journal of Biological Diversity, $\quad$ 18(2), 555-559. https://doi.org/10.13057/biodiv/d180216

Hartati, S., Nandariyah, Y. A., \& Djoar, D. (2014). Genetic diversity of orchid Coelogyne spp by molecular RAPD (Random Amplified Polymorphic DNA) markers. International Journal of Applied Agricultural Research, 9(2), 147-154. 
https://www.ripublication.com/ijaarv3/ijaar v9n2_07.pdf

Herliana, O., Rokhminarsi, E., Mardini, S., \& Jannah, M. (2018). Pengaruh jenis media tanam dan aplikasi pupuk hayati mikoriza terhadap pertumbuhan, pembungaan, dan infeksi mikoriza pada tanaman anggrek Dendrobium sp. Kultivasi, 17(1), 550-557. https://doi.org/10.24198/kultivasi.v17i1.15 774

Kuehnle, A. R. (2007). Orchids, Dendrobium. In N. O. Anderson (Ed.), Flower Breeding and Genetics, Issues, Challenges and Opportunities for the 21 st Century (pp. 539560). Springer, Dordrecht. https://doi.org/10.1007/978-1-4020-44281_20

Niknejad, A., Kadir, M., Kadzimin, S., Abdullah, N., \& Sorkheh, K. (2009). Molecular characterization and phylogenetic relationships among and within species of Phalaenopsis (Epidendroideae: Orchidaceae) based on RAPD analysis. African Journal of Biotechnology, 8(20), 5225-5240. https://www.ajol.info/index.php/ajb/article/ view/65954

Purba, B. R. M., \& Saptadi, D. (2019). Karakterisasi beberapa jenis anggrek berdasarkan karakter morfologi. Jurnal Produksi Tanaman, 7(7). http://protan.studentjournal.ub.ac.id/index. $\mathrm{php} / \mathrm{protan} /$ article/view/1173

Sukma, D., \& Setiawati, A. (2010). Pengaruh waktu dan frekuensi aplikasi pupuk daun terhadap pertumbuhan dan pembungaan anggrek Dendrobium 'Tong chai gold'. Jurnal Hortikultura Indonesia, 1(2), 96103.

https://doi.org/10.29244/jhi.1.2.96-103

Suradinata, Y., Nuraini, A., \& Setiadi, A. (2012). Pengaruh kombinasi media tanam dan konsentrasi pupuk daun terhadap pertumbuhan tanaman anggrek Dendrobium sp. pada tahap aklimatisasi. Jurnal Agrivigor, 11(2), 104-116. https://pustaka.unpad.ac.id/archives/13915 8

Surtinah, S., \& Mutryarny, E. (2013). Frekuensi pemberian grow quick LB terhadap pertumbuhan bibit anggrek dendrobium pada stadia komunitas pot. Jurnal Ilmiah Pertanian, 10(2), 31-40. https://journal.unilak.ac.id/index.php/jip/ar ticle/view/1340

Widiastoety, D. (2008). Pengaruh $\mathrm{KNO}_{3}$ dan $\left(\mathrm{NH}_{4}\right)_{2} \mathrm{SO}_{4}$ terhadap pertumbuhan bibit anggrek vanda. Jurnal Hortikultura, 18(3), 307-311.

http://ejurnal.litbang.pertanian.go.id/index. php/jhort/article/view/858 